\title{
Front Matter: Volume 11346
}

, "Front Matter: Volume 11346," Proc. SPIE 11346, Advances in Ultrafast Condensed Phase Physics II, 1134601 (13 May 2020); doi:

$10.1117 / 12.2571382$

SPIE. Event: SPIE Photonics Europe, 2020, Online Only 


\title{
PROCEEDINGS OF SPIE
}

\section{Advances in Ultrafast Condensed Phase Physics II}

\author{
Stefan Haacke \\ Sangeeta Sharma \\ Vladislav Yakovlev \\ Editors \\ 6-10 April 2020 \\ Online Only, France \\ Sponsored by \\ SPIE \\ Cosponsored by \\ City of Strasbourg (France) \\ Eurometropole (France) \\ CNRS (France) \\ iCube (France) \\ Université de Strasbourg (France) \\ Cooperating Organisations \\ Photonics 21 (Germany) \\ EOS-European Optical Society (Germany) \\ Photonics Public Private Partnership (Belgium) \\ Photonics France (France) \\ Published by \\ SPIE
}

Volume 11346 
The papers in this volume were part of the technical conference cited on the cover and title page. Papers were selected and subject to review by the editors and conference program committee. Some conference presentations may not be available for publication. Additional papers and presentation recordings may be available online in the SPIE Digital Library at SPIEDigitalLibrary.org.

The papers reflect the work and thoughts of the authors and are published herein as submitted. The publisher is not responsible for the validity of the information or for any outcomes resulting from reliance thereon.

Please use the following format to cite material from these proceedings:

Author(s), "Title of Paper," in Advances in Ultrafast Condensed Phase Physics II, edited by Stefan Haacke, Sangeeta Sharma, Vladislav Yakovlev, Proceedings of SPIE Vol. 11346 (SPIE, Bellingham, WA, 2020) Seven-digit Article CID Number.

ISSN: 0277-786X

ISSN: 1996-756X (electronic)

ISBN: 9781510634640

ISBN: 9781510634657 (electronic)

Published by

SPIE

P.O. Box 10, Bellingham, Washington 98227-0010 USA

Telephone +13606763290 (Pacific Time) · Fax +13606471445

SPIE.org

Copyright @ 2020, Society of Photo-Optical Instrumentation Engineers.

Copying of material in this book for internal or personal use, or for the internal or personal use of specific clients, beyond the fair use provisions granted by the U.S. Copyright Law is authorized by SPIE subject to payment of copying fees. The Transactional Reporting Service base fee for this volume is $\$ 21.00$ per article (or portion thereof), which should be paid directly to the Copyright Clearance Center (CCC), 222 Rosewood Drive, Danvers, MA 01923. Payment may also be made electronically through CCC Online at copyright.com. Other copying for republication, resale, advertising or promotion, or any form of systematic or multiple reproduction of any material in this book is prohibited except with permission in writing from the publisher. The CCC fee code is $0277-$ $786 \times / 20 / \$ 21.00$.

Printed in the United States of America by Curran Associates, Inc., under license from SPIE.

Publication of record for individual papers is online in the SPIE Digital Library.

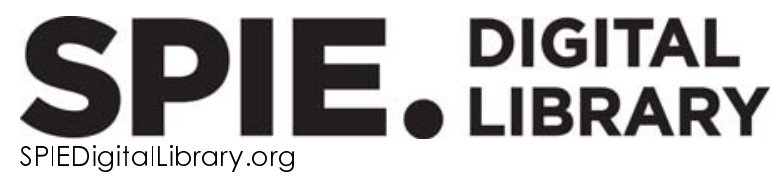

Paper Numbering: Proceedings of SPIE follow an e-First publication model. A unique citation identifier (CID) number is assigned to each article at the time of publication. Utilization of CIDs allows articles to be fully citable as soon as they are published online, and connects the same identifier to all online and print versions of the publication. SPIE uses a seven-digit CID article numbering system structured as follows:

- The first five digits correspond to the SPIE volume number.

- The last two digits indicate publication order within the volume using a Base 36 numbering system employing both numerals and letters. These two-number sets start with $00,01,02,03,04$, 05, 06, 07, 08, 09, OA, OB ... 0Z, followed by 10-1Z, 20-2Z, etc. The CID Number appears on each page of the manuscript. 


\title{
Contents
}

\author{
$\checkmark \quad$ Authors \\ vii Conference Committee
}

STRONGLY CORRELATED MATERIALS

11346 OD Combined ultrafast spectroscopy techniques discloses the microscopic electron lattice interplay behind charge density waves [11346-13]

POSTER SESSION

11346 OT First-principles method based electronic transport properties of two-dimensional $\mathrm{SnSe}_{2(1-x)} \mathrm{X}_{2 \mathrm{x}}$ alloys [11346-30] 
Proc. of SPIE Vol. $113461134601-4$ Downloaded From: https://www.spiedigitallibrary.org/conference-proceedings-of-spie on 26 Apr 2023
Terms of Use: https://www.spiedigitallibrary.org/terms-of-use 


\section{Authors}

Numbers in the index correspond to the last two digits of the seven-digit citation identifier (CID) article numbering system used in Proceedings of SPIE. The first five digits reflect the volume number. Base 36 numbering is employed for the last two digits and indicates the order of articles within the volume. Numbers start with 00, 01, 02, 03, 04, 05, 06, 07, 08, 09, 0A, 0B...0Z, followed by 10-1Z, 20-2Z, etc.

Ahmad, Shahzad, 0T

Bilal, Asif, OT

Carpene, E., OD

Ceraso, A., OD

Cerullo, G., OD

Clark, S. R., OD

Da Como, E., OD

Dal Conte, S., OD

Dallera, C., OD

Hedayat, H., OD

lezekiel, Stavros, ОT

Jalil, Osama, OT

Liu, Xinke, OT

Sayers, C., OD

van Wezel, J., OD

Wee Ang, Kah, OT

Younis, Usman, OT 
Proc. of SPIE Vol. 11346 1134601-6 Downloaded From: https://www.spiedigitallibrary.org/conference-proceedings-of-spie on 26 Apr 2023
Terms of Use: https://www.spiedigitallibrary.org/terms-of-use 


\title{
Conference Committee
}

\author{
Symposium Chairs
}

Francis Berghmans, Vrije Universiteit Brussel (Belgium)

Thierry Georges, Oxxius SA (France)

Paul C. Montgomery, Université de Strasbourg (France)

Lluis Torner, ICFO Barcelona (Spain)

Conference Chairs

Stefan Haacke, Institut de Physique et chimie des Matériaux de Strasbourg (France)

Sangeeta Sharma, Max-Born-Institut für Nichtlineare Optik und Kurzzeitspektroskopie (Germany)

Vladislav Yakovlev, Max-Planck-Institut für Quantenoptik (Germany)

Conference Program Committee

Joachim Burgdörfer, Technische Universität Wien (Austria)

Giulio N. Cerullo, Politecnico di Milano (Italy)

F. Javier García de Abajo, ICFO - Institut de Ciències Fotòniques (Spain)

Peter Hommelhoff, Friedrich-Alexander-Universität Erlangen-Nürnberg (Germany)

Misha Ivanov, Max-Born-Institut für Nichtlineare Optik und

Kurzzeitspektroskopie (Germany)

Maciej Lorenc, CNRS-Rennes (France)

Hamed Merdji, CEA-Saclay (France)

Doris E. Reiter, Westfälische Wilhelms-Universität Münster (Germany)

Martin Schultze, Technische Universität Graz (Austria)

Nicolas Tancogne-Dejean, Max Planck Institute for the Structure and Dynamics of Matter (Germany)

\section{Session Chairs}

1 Novel Experimental and Theoretical Tools

Shunsuke A. Sato, Max-Planck-Institut für Struktur und Dynamik der Materie (Germany)

2 Magnetism and Phase Transitions

Christoph Lange, Universität Regensburg (Germany) 
3 Strongly Correlated Materials

Valérie Halté, Institut de Physique et de Chimie des Matériaux de Strasbourg (France)

$4 \quad$ Strong-field Processes I

Koichiro Tanaka, Kyoto University (Japan)

5 Strong-field Processes II

Vladislav S. Yakovlev, Max-Planck-Institut für Quantenoptik (Germany)

6 Atomically Thin Materials and Topological Materials Yves Acremann, ETH Zurich (Switzerland)

7 Molecular Systems in the Condensed Phase

Stefan Haacke, Institut de Physique et de Chimie des Matériaux de Strasbourg (France) 